\title{
The Impact of the Crisis on the Polarization of Spanish Wages"
}

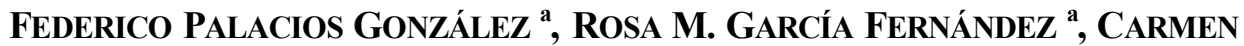 \\ M. LLORCA RODRÍGUEZ ${ }^{\mathrm{a}}$ \\ a Universidad de Granada, Facultad CC.EE., Campus de la Cartuja, s/n, 18071 Granada, España. \\ E.-mail: fpalacio@ugr.es, rosamgf@ugr.es, cmllorca@ugr.es
}

\begin{abstract}
This paper evaluates the impact of the economic downturn on Spanish wage polarization. Using the index of polarization of Palacios-González and García-Fernández (2012), we have computed polarization structuring the earners population into groups according to their wages, gender, education, branch of activity, job status and type of contract. Our results show an increase of wage polarization in all the considered categories except for the type of contract and the branch of activity. This increase in polarization is resulting in social tensions and it must be taken into consideration by policy-makers in the economic and social fields.
\end{abstract}

Keywords: Coefficient of Determination, Inequality, ANOVA Models, Polarization.

\section{El impacto de la crisis en la polarización de los salarios en España}

\begin{abstract}
RESUMEN
Este artículo evalúa el impacto de la recesión económica en la polarización de los salarios en España. Utilizando el índice de polarización de Palacios-González y García-Fernández (2012) se ha calculado la polarización salarial estructurando la población en grupos atendiendo a las siguientes variables: salario percibido, género, educación, rama de actividad, duración de la jornada laboral y tipo de contrato. Los resultados obtenidos muestran un aumento de la polarización en todas las categorías consideradas con la excepción del tipo de contrato y la rama de actividad. Este aumento en la polarización está acentuando las tensiones sociales y, por tanto, debe tenerse en cuenta en el diseño de políticas económicas y sociales.
\end{abstract}

Palabras clave: Coeficiente de determinación, desigualdad, modelos ANOVA, polarización.

JEL Classification: C01, C13, D63, J01, J30

\footnotetext{
* We thank the two anonymous referees for their positive and constructive comments and suggestions.
}

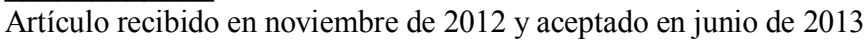

Artículo disponible en versión electrónica en la página www.revista-eea.net, ref. ə-32101 


\section{INTRODUCTION}

Wage polarization has been studied at great length in several countries, above all in the U.S.A. (Harrison and Bluestone, 1990, Ezcurra et al., 2005; Goldin and Katz, 2007; Croci Angelini et al., 2009 and Poggi and Silber, 2010), because it increases social unrest and results in fiscal strain on traditional welfare programs (Kuhn, 1995). However, research on the Spanish economy is scarce and, as far as we are aware, it does not pay attention to the impact of the economic crisis. Nonetheless, in a context of an economic downturn, with an increase in unemployment and an increase in real wages due to the Spanish labour market rigidity, it will be interesting to test if wage polarization has increased, widening the wages gap, and raising the risk of social tension and labour conflicts. With regards to this issue, the main aim of this paper is to evaluate the impact of the crisis on wages polarization according to the characteristics of population.

The theoretical conceptualization of income polarization was developed statistically by Wolfson (1994) and Esteban and Ray (1994) independently, though its notion has been used in previous empirical literature. Following Esteban and Ray (1994), the polarization is focused on the extent to which population is grouped around a small number of poles. According to the alienation-identification framework developed by these authors, if there is a high degree of homogeneity (that is, identification) within each group and a high degree of heterogeneity (that is, alienation) across groups, society is polarized. So, alienation captures the antagonism originated by the income difference between individuals that belong to different income groups: an individual feels alienated from others whose income are distant from his or her income. Identification is related to the number of individuals that belong to the same income group of that individual: for any person, the higher the number of people with the same income level that him, the greater the identification that he or she feels. This idea shows the difference between polarization and inequality. An increase in the degree of homogeneity within each group should be considered as diminishing in inequality, while the polarization should increase. Indeed, inequality quantifies the concentration around the global mean; whereas polarization, as previously mentioned, focuses on the concentration around different poles.

Most of the measures of polarization defined since the mid-nineties are based on this alienation-identification framework. We can classify them into two groups: "polarization by characteristics" and "pure income polarization" measures. The first one quantifies alienation by using the individual's income and computes identification by means of a discrete variable that provides a classification of the population into groups according to its distinctive features. The second group encompasses those measures that only use income to quantify 
identification and alienation. The most utilized measures of the first group are those defined by Gradín (2002) and Zhang and Kanbur (2001). In the second group we find the measures of Wofson (1994), Esteban and Ray (1994) and Duclos et al., (2004) (see Gasparini et al., 2008 for more details about this classification).

In this paper, we focus on the approach to polarization of Palacios-González and García-Fernández (2010 and 2012). These authors reformulated the measure of polarization of Zhang and Kanbur (2001) using the decomposition of the variance, instead of the decomposition of the Theil index. They linked the proposed measure to the coefficient of determination of an ANOVA Linear Model and provided an alternative way to analyze wage polarization by labour force characteristics in line, therefore, with the previously mentioned first group of polarization measures. At the same time, it allows us to compare wage groups via the estimated coefficients of the ANOVA model. It should be taken into account that our aim is to assess the evolution of wage polarization in a time of crisis by identifying its explanatory factors and by considering the characteristics of population in employment.

The proposed approach is applied to Spanish wage data for the years 2007 and 2010. We utilize the information provided by the Living Conditions Survey conducted by the National Statistics Institute. We have focused on real gross hourly wage and on the following characteristics of the labour force: level of wage, gender, level of education, branch of activity, type of contract and job status. To enrich the analysis we have obtained standard measures of inequality, namely, the indices of Gini and Theil, and the Low pay rate, in order to compare inequality and polarization and show their different evolution in the analyzed period. The rest of the paper is organized as follows. Section 2 contains the methodology and the results and section 3 concludes.

\section{IS POLARIZATION INCREASING IN THE SPANISH WAGE SYSTEM?}

\subsection{The model}

As previously mentioned, to test if wage polarization has increased from 2007 to 2010 we are going to focus on the approach to polarization proposed by Palacios-González and García-Fernández (2010 and 2012, PG henceforth). These authors departed from the measure of polarization of Zhang and Kanbur (2001, ZK henceforth) and reformulated it using the decomposition of the variance, instead of the decomposition of the Theil index.

ZK considered that polarization was generated by two tendencies that can be considered equivalent to the concepts of identification and alienation introduced by Esteban and Ray (1994). Given a number of groups determinated 
exogenously, as income (wage in our case) difference within the group decreases, differences across groups are magnified and polarization is higher. Similary, given the intra-group differences, the further apart the mean incomes (in our case mean wages) of the groups are, the higher the polarization.

As can be observed, the approach to polarization of ZK links the concept of polarization with dispersion. Nonetheless, ZK quantified these tendencies using the ratio of the between groups inequality to the within group inequality. For this, they used the decomposition of the concentration index of Theil. Later, Silber et al., (2007) used the decomposition of the Gini index to compute the ratio of the between groups inequality to the within group inequality. Note that these publications used concentration indices to compute dispersion.

The measure utilitized in this paper is based on the relationship between dispersion and polarization. In fact, PG reformulated the measure of ZK utilizing the intra-group and the inter-groups variance instead of the intra-group and inter-groups inequality. When the representative magnitude of each group is the mean of the variable of interest, in our case the mean wage, the intra-group variance and the inter-groups variance are the most appropriate approaches to evaluate the homogeneity within a group and the heterogeneity across groups respectively (see for instance Fisher, 1958).

To define the measure of PG, it is proceeded as follows. Given a number of groups determinated exogenously, it is assumed that the wage difference within the group or identification decreases when the wage of the individuals are closer to the average wage of the group to which they belong. It is supposed that heterogeneity or alienation is related to the distance between the mean wages of the groups. The larger the distance or gap, the higher the heterogeneity between groups. In line with the previous arguments, PG defined a polarization index increasing with the wage differences across groups (measured by the inter groups variance) and decreasing with wage differences within group (measured by the intra group variance). It is given by

$$
P^{*}=\frac{\text { Inter groups variance }}{\text { Intra group variance }}=\frac{V_{B}}{V_{W}} \in[0,+\infty]
$$

Note that the above expression, as well as the expression of Zhang and Kanbur, is not normalized, making its interpretation difficult. However, taking into consideration that the variance of the overall population $(V)$ can be broken down into the intra-group variance plus the inter-groups variance, we can normalize $P^{*}$ obtaining ${ }^{1}$

\footnotetext{
${ }^{1}$ Note that $\mathrm{P}=\mathrm{P} * /\left(1+\mathrm{P}^{*}\right)$. That is, $\mathrm{P}$ is obtained by means of an increasing function that preserves the order of the values of $\mathrm{P}^{*}$ and normalizes these values into the interval $[0,1]$.
} 


$$
P=\frac{V_{B}}{V}=1-\frac{V_{W}}{V} \in[0,1]
$$

Multiplied by 100, P can be interpreted as a percentage of polarization.

As has been mentioned previously, one of the main advantages of $\mathrm{P}$ is that it connects the more recent topic of wage polarization to the highly developed topic of Regression via the coefficient of determination $\left(R^{2}\right)$.

To provide a more detailed explanation, let us consider any employee characteristic, for instance education, branch of activity, type of contract, etc. that provides an exhaustive partition of the whole population into $k$ groups or sub-populations $G_{1}, G_{2}, \ldots, G_{k}$.

Let us consider the Linear General Model that explains the wage $\left(Y_{j}\right)$ as a function of selected characteristics of the earners (e.g. branch of activity, type of contract, etc.) that are introduced in the model by means of dummy variables $\left(D_{i}\right)$

$$
Y_{j}=\sum_{i=1}^{k} \beta_{i} D_{i}(j)+u_{j}
$$

where $\beta_{i} i=1,2, \ldots, k$ are the regression parameters; $k$ is the number of groups or sub-populations into which whole population have been divided; $u_{j}$ is the error term which verifies that $E\left[u_{j}\right]=0, V\left(u_{j}\right)=\sigma^{2}$ and $\operatorname{Corr}\left(u_{i}, u_{j}\right)=0$ for all $i \neq j$ and $D_{i}, \forall i=1,2, \ldots, k$, is a dummy variable that is equal to one if the worker $j$ belongs to the groups $i$, and zero in other cases.

Given that the dependent variables $D_{i}(j)$ are dicotomic, model (1) can be interpreted as an ANOVA model ${ }^{2}$ (see for example Gujarati, 1997, p. 490) whose coefficient of determination is equal to measure $\mathrm{P}$.

In matrix notation, model (1) is expressed as

$$
\left(\begin{array}{c}
Y_{1} \\
\vdots \\
Y_{n}
\end{array}\right)=\left(\begin{array}{ccc}
D_{1}(1) & \cdots & D_{k}(1) \\
\vdots & \ddots & \vdots \\
D_{1}(n) & \cdots & D_{k}(n)
\end{array}\right)\left(\begin{array}{c}
\beta_{1} \\
\vdots \\
\beta_{k}
\end{array}\right)+\left(\begin{array}{c}
u_{1} \\
\vdots \\
u_{n}
\end{array}\right)
$$

Let $n_{i}, i=1,2, \ldots, k$, be the number of individuals of the sample that belong to

\footnotetext{
${ }^{2}$ In the empirical applications it is more interesting to eliminate a dummy variable, to avoid collinearity, instead of the constant because the coefficients of the model show the difference between the expected wage of the groups included in the model and the omitted group. So, in section 2.2 we estimated an ANOVA linear intercept model equivalent to (1).
} 
the groups $G_{i}, i=1,2, \ldots, k$. Given that the groups $G_{i}$ constitute a partition of the population and each individual belongs only to one group, it can be inmediately verified that

$$
\left(\mathbf{X}^{\prime} \mathbf{X}\right)=\left(\begin{array}{ccc}
n_{1} & \cdots & 0 \\
\vdots & \ddots & \vdots \\
0 & \cdots & n_{k}
\end{array}\right)
$$

That is, $\left(\mathbf{X}^{\prime} \mathbf{X}\right)$ is a diagonal matrix. In addition

$$
\mathbf{X}^{\prime} \mathbf{Y}=\left(\begin{array}{c}
\sum_{j=1}^{n} D_{1}(j) Y_{j} \\
\vdots \\
\sum_{j=1}^{n} D_{k}(j) Y_{j}
\end{array}\right)
$$

where the $k$ components of the vector $\mathbf{X}^{\prime} \mathbf{Y}$ are the total wage $Y$ in each group. Hence, it is evident that the elements of the least square estimator $\hat{\boldsymbol{\beta}}=\left(\mathbf{X}^{\prime} \mathbf{X}\right)^{-1} \mathbf{X}^{\prime} \mathbf{Y}$, are the sample means of the variable $Y$ in the different groups which are denoted by $\bar{Y}_{i}$.

Two important characteristics of model (1) should be highlighted. Firstly, observe that the model does not present exact collinearity since it does not have intercept. As is well known, exact collinearity can be corrected by removing one dummy variable and mantaining the intercept in the model. There is no difference between the fitted values for $Y$ and the residual of the regression if the intercept, or any of the dummy variables, is removed from the model. Hence, the coefficient of determination is the same in both cases (see for instance Russell and MacKinnon, 2004, pp. 70). Secondly, note that the sum of the residuals of model (1) is zero inspite of the fact that the model does not have intercept. This is because the elements of the rows of matrix $\mathbf{X}$ add up to one (see PG, 2012 for more details) and therefore, the decomposition of the total sum of squares into the explained sum of squares plus the residual sum of squares is valid taking $R^{2}$ values into $[0,1]$.

Taking into consideration that the explained sum of squares (SSE) is given by

$$
S S E=\hat{\beta}^{\prime} X^{\prime} Y-n \bar{Y}^{2}=\sum_{i=1}^{k} n_{i} \bar{Y}^{2}{ }_{i}-n \bar{Y}^{2}
$$

it can be stated that 


$$
\frac{S S E}{n}=\frac{1}{n} \sum_{i=1}^{k} n_{i} \bar{Y}_{i}^{2}-\bar{Y}^{2}
$$

is the inter groups variance.

Denoting the sum of squares by SST it can be easily verified that

$$
\frac{S S E}{S S T}=R^{2}=P
$$

That is, if the variable $Y$ is wage, the polarization measure $P$ is the coefficient of determination of the model that explains the wage in relation to the group to which each earner belongs. This result provides an alternative way to analyze wage polarization by the earners characteristics and, at the same time, allows us to compare sub-populations via the estimated coefficients of the ANOVA model.

In this research, our dependent variable, real gross hourly wage, is obtained by dividing nominal gross monthly wage of SILC for Spain (2007 and 2010) by the total hours worked in a month and deflacting the result by the 2007 based Spanish Consumer Price Index. We compute polarization for three groups defined on the basis on their wages: low paid workers, those whose wage places them among the lowest 20 percent of the wage distribution, normal wage workers and highly paid workers, the latter are those placed among the upper 20 percent of the wage distribution. Additionally, we compute wage polarization for the following characteristics of the worker: branch of activity, type of contract (temporary vs permanent), job status (full-time vs part-time), level of education and gender.

\subsection{Empirical results}

The recession in the Spanish economy was evident in 2010 when the GDP (Gross Domestic Product) contracted 2.9 percent in volume terms with respect to 2007. Construction and Manufactures were the most affected branches of activity and played a significant role at the beginning of the Spanish crisis (García Serrano, 2012). In fact, Construction was the main employment destructive sector in the analysed period due to its greater labour intensity. Real Estate activities and Manufactures also suffered a significant destruction of jobs which was much higher than the overall destruction of employment (9.93 percent). Moreover, it should be highlighted that the crisis has had a greater negative effect on male employment because the most detrimentally affected sectors are heavily male dominated. Nevertheless, the Spanish average hourly wage rose 5.7 percent in 2010 with respect to 2007 (Table 1), revealing the rigidity of the Spanish labour market in wage determination due to the multi-annual character of the large part of the collective agreements. 
Table 1

Summary measures of real gross hourly wage

\begin{tabular}{|l|c|c|c|c|}
\hline & Mean & Gini Index & Theil Index & Lowpay rate \\
\hline 2007 & 10.544 & 0.284 & 0.138 & 0.071 \\
\hline 2010 & 11.148 & 0.273 & 0.125 & 0.055 \\
\hline $2007-2010$ Percentage Change & 5.7 & -3.9 & -9.4 & -22.5 \\
\hline
\end{tabular}

Source: Our own elaboration on Spanish SILC.

In this context, our results show that polarization enhanced in 2010 (see model 1 in Table 2). As a result of this, there has been an increase in the level of antagonism between low paid workers and the rest of the employees. This finding is relevant since Fernández-Macías (2012) showed that, between 1995 and 2007, the technical change did not have a polarizing impact on the Spanish employment structure as it had in other European countries. On the contrary, Spain recorded a relative expansion of mid level jobs in the wage/skills hierarchy due to the bubble in the Construction sector.

If we pay attention to the job status or the level of education perspectives (model 3 and 6 in Table 2, respectively), the intensity of this trend is more marked since they registered an increase of polarization of 45.45 percent and 6.25 percent, respectively. The worsening of the average hourly wage of parttime workers compared with the full-time workers is especially striking, taking into account the traditional higher precariousness of that collective (Muñoz del Bustillo Llorente et al., 2008; Fernández-Kranz y Rodríguez-Planas, 2010 and 2011) and that part-time jobs grew 2.1 percent in the 2007-2010 period, and a large proportion of part time workers are in this situation as a last resort (model 6 in Table 2). Thus, the social tension risk could be accentuated in Spain since, as pointed out by Moral Carcedo et al., (2012), this increase in part-time work can be identified as an attempt to cushion the impact of the unemployment of the main breadwinner on households' income. Moreover, the high involuntariness of this part-time work shows a worsening of job quality in Spain (Merino Llorente et al., 2012) that makes it difficult to achieve the goals of the 2020 Strategy of the European Union. In addition, the less qualified groups in the Spanish labour force, almost the 50 percent of it, have been strongly punished by the economic recession, and have suffered higher employment destruction owing to the clear shortcomings of labour market and productive system in Spain (Garrido Medina, 2012). Therefore, a strong effort should be made to reinforce the Spanish education system in order to increase the qualification of the Spanish labour force and improve its effectiveness in adapting it to the needs of economic activity.

In fact, the hourly wage polarization increased for all the perspectives considered in our analysis except the contractual type and the branch of activity 
(model 5 and 4 in Table 2, respectively). In the case of the analysis comparing temporary and permanent wage contracts, polarization decreased owing to the much higher rate of growth registered by the average hourly wage of the temporary workers, almost 6.73 times more than the permanent workers wage. This difference was more distinct for women. The decrease of the coefficients of the model in 2010 with respect to 2007 verifies this rapprochement between the group averages. This is coherent with the homogeneous wage improvement for temporary workers and the wage decrease for permanent workers with intermediate wages found by Motellón et al., (2010) as consequence of labour market reforms in Spain since 1994. As for the branch of activity criterion, the polarization decreased 7.37 percent due to the approach of the group averages, as well (model 4 in Table 2). Our reference category in this case is Other Activities and Services that includes Public Administration and Services in which wages have remain more stable during the analysed period.

If we pay attention to the coefficients of the ANOVA models, we must stress that the differences in the average hourly wage by gender (model 2 in Table 2) are unfavourable for women, although the polarization measure for this criterion is the lowest in the analysed years ( 0.9 percent and 0.91 percent, respectively). It should be highlighted that the intra-group identification for women is weak and that it implies diminishing polarization. In fact, in the female labour force there is a higher proportion of less skilled workers (Centro de Estudios del Cambio Social, 2011, p. 322) reflecting a wide gender gap while the most qualified women have similar wages to men (De la Rica et al., 2008)

Furthermore, the level of education (model 3 in Table 2) provokes significant positive differences between the categories introduced in the model and the reference category (up to elementary school level) that is, the average hourly wage grows with the level of academic studies, this feature being more intense in 2010. It should be stressed that the occupations of less skilled collectives are highly punished by the Spanish labour market, which suffers a chronic growth in the unemployment of these social collectives (Garrido Medina, 2012).

Differences in the average hourly wage can also be stated from a branch of activity perspective. All the economic sectors, except the Financial one, registered a lower wage than our reference category, Other Activities and Services that includes Public Administration and Services and Education Services. The reference category recorded a higher hourly wage jointly with Financial Services. The higher average hourly wage received by the Financial sector workers is stressed in 2010, when the coefficient of most of the activities got closer, showing a decrease of their distance with respect to the reference category. The growth of the average hourly wage for Public Administration and Services and Education Services was much lower than that of the rest of branch. Only the Real Estate wages increased less than did Education Services wages but it grew 
above Public Administration and Services wages despite the bursting of the Construction bubble.

Table 2

Estimated ANOVA models ${ }^{3}$

\begin{tabular}{|c|c|c|}
\hline & \multicolumn{2}{|c|}{ Coefficients } \\
\hline & 2007 & 2010 \\
\hline \multicolumn{3}{|l|}{ Model 1: Wage } \\
\hline Low paid & $\begin{array}{l}-4.725^{\star * *} \\
(0.0420)\end{array}$ & $\begin{array}{l}-4.856^{\star \star *} \\
(0.0497)\end{array}$ \\
\hline High paid & $\begin{array}{l}12.50^{* * *} \\
(0.184)\end{array}$ & $\begin{array}{l}12.13^{* * *} \\
(0.198)\end{array}$ \\
\hline Constant & $\begin{array}{l}9.611^{* * *} \\
(0.0349)\end{array}$ & $\begin{array}{l}10.23^{* * *} \\
(0.0414)\end{array}$ \\
\hline F-test & $10089.2^{\star \star *}$ & $7.934 .42^{\star \star \star}$ \\
\hline $\mathrm{R}^{2}$ & 0.689 & 0.697 \\
\hline $\mathrm{R}^{2}$ percentage change & - & 1.16 \\
\hline Reference Variable: "Normal" wage & & \\
\hline \multicolumn{3}{|l|}{ Model 2: Gender } \\
\hline Female & $\begin{array}{c}-1.148^{* * *} \\
(0.130)\end{array}$ & $\begin{array}{c}-1.167^{\star \star *} \\
(0.146)\end{array}$ \\
\hline Constant & $\begin{array}{l}11.07^{* \star *} \\
(0.0948)\end{array}$ & $\begin{array}{l}11.68^{\star * *} \\
(0.104)\end{array}$ \\
\hline F-test & $78.56^{\star \star *}$ & $63.89^{* * *}$ \\
\hline $\mathrm{R}^{2}$ & 0.009 & 0.0091 \\
\hline$R^{2}$ percentage change & - & 1.11 \\
\hline Reference Variable: Male & & \\
\hline \multicolumn{3}{|l|}{ Model 3: Level of Education } \\
\hline Secondary & $\begin{array}{l}-0.283^{* *} \\
(0.136)\end{array}$ & $\begin{array}{c}0.436^{* * *} \\
(0.138)\end{array}$ \\
\hline Highschool & $\begin{array}{l}1.296^{\star * *} \\
(0.154)\end{array}$ & $\begin{array}{c}2.054^{* * *} \\
(0.170)\end{array}$ \\
\hline Tertiary & $\begin{array}{l}5.600^{* * *} \\
(0.173)\end{array}$ & $\begin{array}{l}6.200^{* * *} \\
(0.173)\end{array}$ \\
\hline Constant & $\begin{array}{c}8.202^{\star \star \star} \\
(0.113)\end{array}$ & $\begin{array}{c}7.986^{* * *} \\
(0.111)\end{array}$ \\
\hline F-test & $538.88^{\star \star \star}$ & $544.11^{\star * *}$ \\
\hline $\mathrm{R}^{2}$ & 0.176 & 0.187 \\
\hline $\mathrm{R}^{2}$ percentage change & - & 6.25 \\
\hline Reference Variable: Up to elementary school & & \\
\hline
\end{tabular}

${ }^{3}$ Although the $R^{2}$ are small, the ANOVA F-Tests are significantly distinct from zero with pvalues of order less than 0.01 in all cases. This is due to the sample size being extraordinarily big and the potency of the contrast is very high. 
Table 2 (continue)

Estimated ANOVA models

\begin{tabular}{|c|c|c|}
\hline & \multicolumn{2}{|c|}{ Coefficients } \\
\hline & 2007 & 2010 \\
\hline \multicolumn{3}{|l|}{ Model 4: Branch of Activity } \\
\hline Agriculture & $\begin{array}{c}-5.565^{\star * *} \\
(0.216)\end{array}$ & $\begin{array}{c}-5.114^{\star \star \star} \\
(0.257)\end{array}$ \\
\hline Manufacturing & $\begin{array}{c}-2.126^{\star * *} \\
(0.189)\end{array}$ & $\begin{array}{c}-1.746^{\star \star \star} \\
(0.196)\end{array}$ \\
\hline Construction & $\begin{array}{c}-3.373^{* * *} \\
(0.195)\end{array}$ & $\begin{array}{c}-2.899^{* * *} \\
(0.210)\end{array}$ \\
\hline 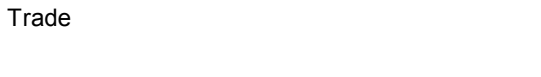 & $\begin{array}{c}-4.290^{* * *} \\
(0.176)\end{array}$ & $\begin{array}{c}-3.895^{\star * *} \\
(0.189)\end{array}$ \\
\hline Hotel & $\begin{array}{c}-4.932^{\star * *} \\
(0.196)\end{array}$ & $\begin{array}{c}-4.633^{* * *} \\
(0.225)\end{array}$ \\
\hline Transport & $\begin{array}{c}-1.712^{\star * *} \\
(0.270)\end{array}$ & $\begin{array}{c}-1.043^{\star * *} \\
(0.300)\end{array}$ \\
\hline Financial & $\begin{array}{l}1.933^{* * *} \\
(0.513)\end{array}$ & $\begin{array}{c}2.641^{* \star *} \\
(0.561)\end{array}$ \\
\hline Real Estate & $\begin{array}{c}-1.136^{\star * *} \\
(0.307)\end{array}$ & $\begin{array}{l}-1.037 \\
(0.852)\end{array}$ \\
\hline Constant & $\begin{array}{c}12.42^{* * *} \\
(0.132)\end{array}$ & $\begin{array}{c}12.52^{* * *} \\
(0.123)\end{array}$ \\
\hline F-test & $157.76^{\star \star \star}$ & $113.92^{\star * *}$ \\
\hline $\mathrm{R}^{2}$ & 0.095 & 0.088 \\
\hline $\mathrm{R}^{2}$ percentage change & - & -7.37 \\
\hline Reference Variable: Other activities and services & & \\
\hline \multicolumn{3}{|l|}{ Model 5: Type of Contract } \\
\hline Temporal C. & $\begin{array}{c}-3.596^{* * *} \\
(0.117)\end{array}$ & $\begin{array}{c}-2.818^{\star * *} \\
(0.169)\end{array}$ \\
\hline Constant & $11.53^{* * *}$ & $11.74^{\star * \star}$ \\
\hline $\begin{array}{l}\text { F-test } \\
\mathrm{R}^{2} \\
\mathrm{R}^{2} \text { percentage change } \\
\text { Reference Variable: Permanent Contract }\end{array}$ & $\begin{array}{c}(0.117) \\
950.96^{\star \star \star} \\
0.068 \\
-\end{array}$ & $\begin{array}{c}(0.0833) \\
279.48^{\star * *} \\
0.036 \\
-47.06\end{array}$ \\
\hline \multicolumn{3}{|l|}{ Model 6: Job Status } \\
\hline Part time & $\begin{array}{c}-2.039^{* * *} \\
(0.174)\end{array}$ & $\begin{array}{c}-2.313^{* * *} \\
(0.232)\end{array}$ \\
\hline Constant & $\begin{array}{l}10.78^{* * *} \\
(0.0710)\end{array}$ & $\begin{array}{l}11.43^{\star * *} \\
(0.0776)\end{array}$ \\
\hline F-test & $137^{\star \star \star}$ & $99.18^{* * *}$ \\
\hline $\mathrm{R}^{2}$ & 0.011 & 0.016 \\
\hline$R^{2}$ percentage change & - & 45.45 \\
\hline Reference Variable: Full-time job & & \\
\hline
\end{tabular}

Robust standard errors in parentheses; ${ }^{* * *} p<0.01,{ }^{* *} p<0.05,{ }^{*} p<0.1$

Source: Our own elaboration on Spanish SILC. 
The worsening of the polarization has been accompanied by a reduction in wage inequality. The Gini and Theil indices fell 3.87 and 9.2 percent, respectively. The low pay rate, that is the percentage of wage earners with a hourly wage below two thirds of the median wage, also decreased from 0.070 to 0.055 (see Table 1). These results are in line with those obtained by Simón (2009), who found a reduction in the wage inequality in Spain and put it down to the changes in the patterns of the economic agents, above all, level of education, occupation, contract and collective agreement types ${ }^{4}$.

Broadly speaking, the reduction in the homogeneity within group has involved a decrease in inequality but, in addition, an increase in wage polarization in Spain (see, Esteban and Ray, 1994). This could be a factor in social unrest but, at the same time, an incentive to quicken the adjustment of Spanish economy to a new model based on new found knowledge. In this respect, a strengthening of skilled labour should be sought through the reform of the education system and, to avoid the short-term hardship of this transition for lessskilled workers, the social safety net should be reorganized.

\section{CONCLUSIONS}

The rigidity of the wage settlement process in Spain caused a growth of the average hourly wage despite the economic downturn in the period 2007-2010. In that context, hourly wage inequality decreased according to the indices of Gini and Theil; but wage polarization increased, opening the gap between low pay and the rest of workers. This polarization increment is verified from the perspectives of job status, education level and gender showing the higher impact of the crisis on the most vulnerable collectives of the Spanish labour market: part-time and less skilled workers. These results are in line with the conclusions of previous research which showed the impact of the Construction bubble on the Spanish wage hierarchy, the worsening of the job quality in the country to the detriment of the less skilled groups in the Spanish labour market.

On the other hand, we have to stress the decrease in polarization for the contractual type and branch of activity criteria. In these cases, it decreased owing to the loss of bargaining power of permanent workers with intermediate wages found by previous research and the rapprochement of most sectors to Other Activities and services branch in which wages have remain more stable during the analyzed period since it includes Public Administration and Services.

In addition, our findings state significant and positive differences in the average hourly wages for men, high-skilled workers, full-time jobs and for

\footnotetext{
${ }^{4}$ The heterogeneity of these features was identified as causing greater wage inequality in Spain than in other neighbouring countries by Abadie (1997), Jimeno et al., (2001) and Palacio and Simón (2004).
} 
those working in Financial and Other Activities and services sectors. So, social instability and fiscal strain on social welfare program could increase in Spain. To mitigate these polarization effects, wide sweeping reforms are necessary in the economic specialization, educational and other social policy areas in order to diversify the economic activity, to increase the skill of the labour force and to reinforce the gender equity initiatives.

\section{REFERENCES}

ABADIE, A. (1997). "Changes in Spanish Labor Income Structure during the 1980's: A Quantile Regression Approach", Investigaciones Económicas, 21, pp. 253-272.

CENTRO DE ESTUDIOS DEL CAMBIO SOCIAL (2011). Informe España 2011. Una interpretación de su realidad social. Fundación Encuentro. http://www.fund-encuentro.org.

CROCI ANGELINE E., FARINA, F. and PIANTA, M. (2009). "Innovation and Wage Polarisation in Europe". International Review of Applied Economics, 23 (3), pp. 309-325.

DE LA RICA, S., DOLADO, J. and LLORENS, V. (2008). "Ceilings or floors? Gender wage gaps by education in Spain". Journal of Population Econo-mics, 21(3), pp. 777-78.

DUCLOS, J. Y., ESTEBAN J.M., and RAY D. (2004). "Polarization: Concepts, Measurement, Estimation". Econometrica 74, pp.1337-1772.

ESTEBAN, J.,M., and RAY, D. (1994). "On the Measurement of Polarization". Econometrica, 62, pp. 819-851.

EZCURRA, R., GIL, C., PASCUAL, P. and RAPÚN, M. (2005). "Inequality, polarisation and regional mobility in the European Union”. Urban Studies, 42 (7), pp. 1057-1076.

FERNANDEZ KRANZ, D. and RODRÍGUEZ-PLANAS, N., (2010). "El Contrato a Tiempo Parcial". Papeles de Economía Española, 124, pp. 148-163.

FERNÁNDEZ-KRANZ,D. and RODRÍGUEZ-PLANAS, N. (2011). "The part-time pay penalty in a segmented labor market”. Labour Economics, 18 (5), pp. 591-606.

FERNÁNDEZ-MACÍAS, E. (2012). "Job Polarization in Europe? Changes in the Employment Structure and Job Quality, 1995-2007". Work and Occupations, 39 (2), pp. 157-182.

FISHER, W., D. (1958). "On Grouping for Maximum Homogeneity". Journal of the American Statistical Association, 53 (284), pp. 789-798.

GARCÍA SERRANO, C. (2012). "Del pasmo al marasmo: El sector de la construcción y su relación con la crisis del empleo". Estudios de Economía Aplicada, 30(1), pp. 163-182.

GARRIDO MEDINA, L. (2012). "Estudios y trabajo de los españoles en la crisis de empleo". Estudios de Economía Aplicada, 30 (1), pp. 291-58.

GASPARINI, L., HORENSTEIN, M., MOLINA, E., and OLIVIERI, S. (2008). Polarización Económica, Instituciones y Conflicto. Santiago de Chile: Ed. Uqbar.

GRADÍN, C. (2002). "Polarization by sub-populations in Spain, 1973-91". Re-view of Income and Wealth, 46 (4), pp. 457-474. 
GOLDIN, C. and KATZ, L. F. (2007). "Long-run Changes in the Wage Structure: Narrowing, Widening, Polarizing". Brookings Papers on Economic Activity, 2, pp. 135-165.

GUJARATI, D., N.(1997). Econometría. Colombia: McGraw-Hill Interamericana.

HARRISON, B. and BLUESTONE, B. (1990). "Wage Polarisation in the U.S. and the Flexibility Debate". Cambridge Journal of Economics, 14 (3), pp. 351-373.

JIMENO, J. F.; IZQUIERDO, M. and HERNANZ, V. (2001). "La desigualdad salarial en España: descomposición y variación por niveles de salario". Pa-peles de Economía Española, 88, pp. 113-125.

KUHN, P. (1995). "Labour Market Polarization: Canada in International Perspective". The Bell Canada Papers on Economic and Social Policy, 4, pp. 283-322.

MERINO LLORENTE, M. C.; SOMARRIBA ARECHAVALA, N. and NEGRO MACHO, A. N. (2012). "Un análisis dinámico de la calidad del trabajo en España. Los efectos de la crisis económica". Estudios de Economía Aplicada, 30 (1), pp. 261-282.

MORAL CARCEDO, J.; GARCÍA BELENGUER-CAMPOS, F. and BOTE ÁLVAREZCARRASCO, V. (2012). "Flexibilidad del tiempo de trabajo en España: ¿Ha alterado la crisis el comportamiento del empleo a tiempo parcial?". Estudios de Economía Aplicada, 30(1), pp. 209-236.

MOTELLÓN, E., LÓPEZ-BAZO, E. and EL-ATTAR, M. (2010). Cambios en la estructura salarial por tipos de contrato, 1995-2002". Revista de Economía Aplicada, 53 (18), pp. 5-38.

MUÑOZ DE BUSTILLO LLORENTE, R., FERNÁNDEZ MACÍAS, E., and ANTÓN PÉREZ, J.I. (2008). El Trabajo a Tiempo Parcial en España en el Contexto de la Unión Europea. Ministerio de Trabajo e Inmigración, Colección Informes y Estudios, Serie Empleo, 36

PALACIO, J. I. and SIMÓN, H. (2004). "Dispersión salarial entre estable-cimientos y desigualdad salarial en España". Revista de Economía Aplicada, 36 (12), pp.47-81.

PALACIOS-GONZÁLEZ, F. and GARCÍA-FERNÁNDEZ, R.(2010). "El coeficiente de determinación de un modelo lineal ANOVA como medida de polarización de la renta", Anales de Economía Aplicada, CD ROM, pp. 1753-1770, Delta Publicaciones.

PALACIOS-GONZÁLEZ, F. and GARCÍA-FERNÁNDEZ, R.(2012). "Interpre-tation of the coefficient of determination of an ANOVA model as a measure of polarization". Journal of Applied Statistics, 39 (7), pp. 1543-1555.

POGGI, A. and SILBER, J. (2010). "On polarization and Mobility: A look at Polarization in the Wage-career Profile in Italy". The Review of Income and Wealth, 56 (1), pp.123140.

RUSSELL D. AND MACKINNON J.,G. (2004). Econometric Theory And Methods . New York-Oxford: Oxford University Press.

SILBER, J., DEUTSH J., and HANOKA, M.(2007). "On the link between the concept of Kurtosis and Bi-polarization". Economic Bulletin, 4, pp.1-5.

SIMÓN, H., (2009). "La desigualdad salarial en España: una perspectiva internacional y temporal". Investigaciones Económicas, 23 (3), pp. 439-471.

WOLFSON, M., C.,(1994). "When Inequalities Diverge?". American Economic Review, 84, pp.353-58.

ZHANG, X. and KANBUR R. (2001). "What Difference Do Polarization Mea-sures Make? An Application to China". Journal of Development Studies, 37, pp. 85-98. 